\begin{tabular}{|l|l|}
\hline $\begin{array}{l}\text { 2. To: (Receiving Organization) } \\
\text { Distribution }\end{array}$ & $\begin{array}{l}\text { 3. From: (Originating Organization) } \\
\text { PFP Transition Engineering }\end{array}$ \\
\hline 5. Proj./Prog./Dept./Div.: & 6. Cog. Engr.: \\
W-460 & DW Nelson \\
\hline
\end{tabular}

8. Originator Remarks:

This project-specific Quality Assurance Program Plan is being issued for Project W-460, Plutonium Stabilization \& Handling.

11. Receiver Remarks:
4. Related EDT No.:

N/A

7. Purchase Order No.

$\mathrm{N} / \mathrm{A}$

9. Equip./Component No.:

N/A

10. System/Bldg./Facility:

PFP

12. Major Assm. Dwg. No.:

N/A

13. Permit/Permit Application No.:

N/A

14. Required Response Date:

$4 / 10 / 98$

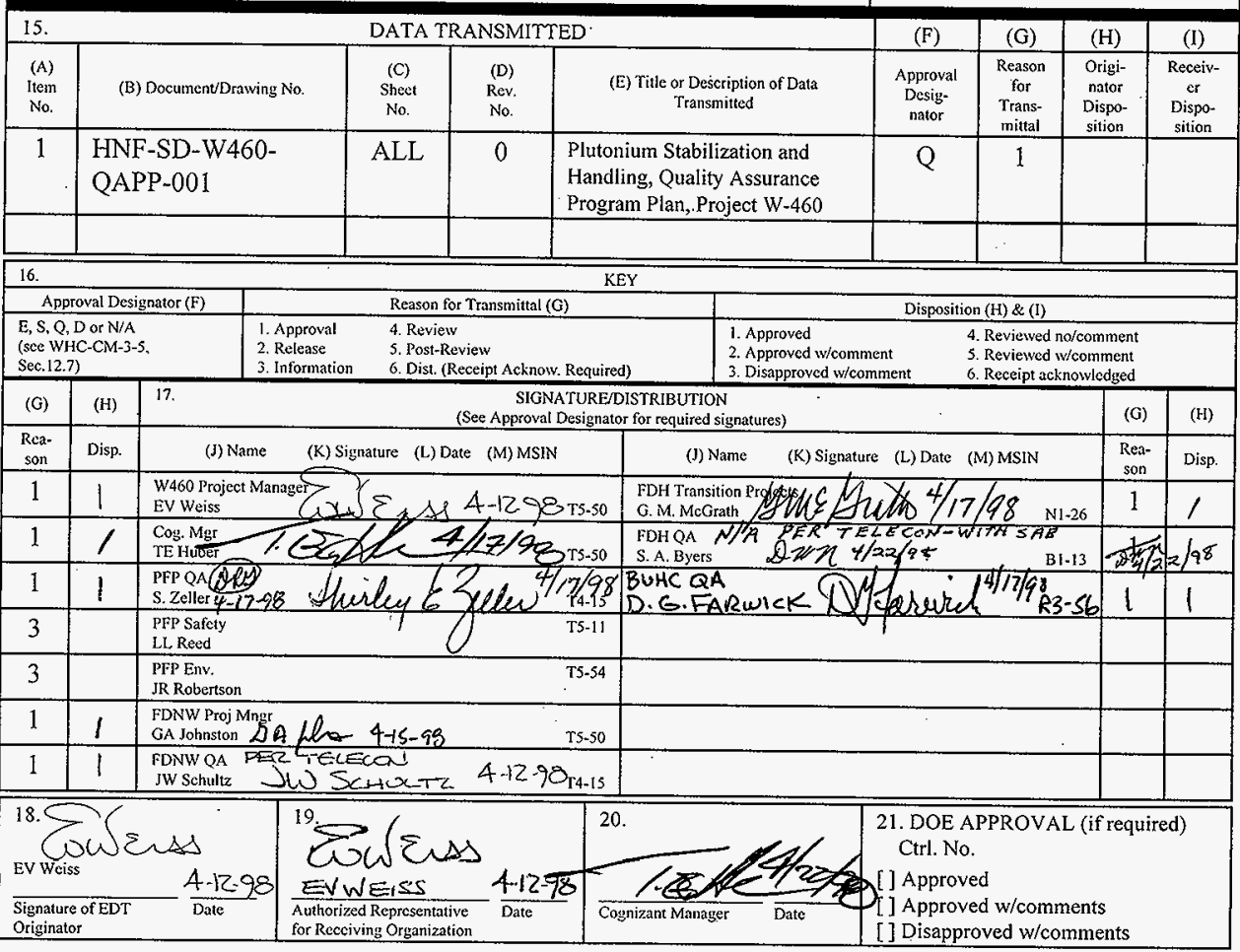




\title{
Plutonium Stabilization and Handling Quality Assurance Program Plan
}

\author{
Evelyn V. Weiss
}

B\&W Hanford Co., Richland, WA 99352

U.S. Department of Energy Contract DE-AC06-96RL13200

EDT/ECN: 617726

Org Code: $15 \mathrm{CO0}$

B\&R Code: EW7003000
UC: 721

Charge Code: K6182 HAN97400

Total Pages: 32

Key Words: Plutonium, PFP, Stabilization, Handling, SNM, W-460, Storage, Vault, PuSH, 94-1, Quality, QAPP

Abstract: This Quality Assurance Program Plan (QAPP) identifies project quality assurance requirements for all contractors involved in the planning and execution of Hanford Site activities for design, procurement, construction, testing and inspection for Project W-460, Plutonium Stabilization and Handling. The project encompasses procurement and installation of a Stabilization and Packaging System (SPS) to oxidize and package for long term storage remaining plutonium-bearing special nuclear materials currently in inventory at the Plutonium Finishing Plant (PFP), and modification of vault equipment to allow storage of resulting packages of stabilized SNM.

TRADEMARK DISCLAIMER. Reference herein to any specific commercial product, process, or service by trade name, trademark, manufacturer, or otherwise, does not necessarily constitute or imply its endorsement, recommendation, or favoring by the United States Government or any agency thereof or its contractors or subcontractors.

Printed in the United States of America. To obtain copies of this document, contact: Document Control Services, P.O. Box 950, Mailstop H6-08, Richland WA 99352, Phone (509) 372-2420;

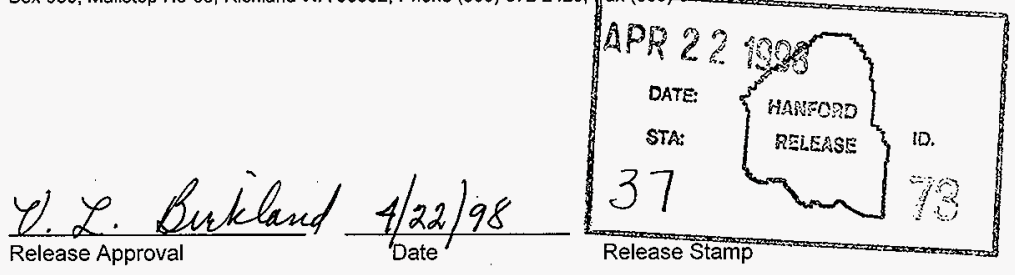

\section{Approved for Public Release}


BWHC-9853379AR3

ATTACHMENT

CONSISTING OF 34 PAGES INCLUDING COVER SHEET 
Project Hanford Management Contract

\title{
QUALITY ASSURANCE PROGRAM PLAN
}

\author{
$B \& W$ Hanford Co. \\ and
}

Fluor Daniel NorthWest

Plutonium Stabilization and Handling

Project W-460

\author{
HNF-SD-W460-QAPP-001 \\ Revision 0
}

B\&W HANFORD CO.

February 1998 
HNF-SD-W460-QAPP-001

Rev. 0

B\&W Hanford Co.

Plutonium Finishing Plant

QUALITY ASSURANCE PROGRAM PLAN

Plutonium Stabilization and Handling

Project W-460

Approvals:

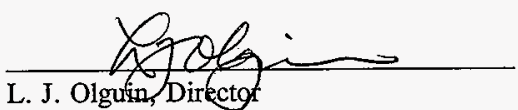

Facility Transition Projects

Fluor Daniel Hanford

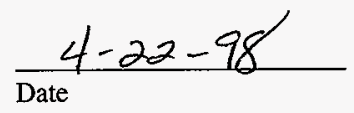

$4-12-98$

Date

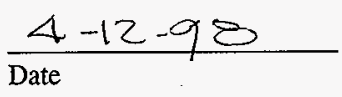

J. W. Schultz

Quality Assurance Engineer

Fluor Daniel Northwest

Balance of Approvals are Located on EDT 617726

ii 
Table of Contents

Table of Contents $\ldots \ldots \ldots \ldots \ldots \ldots \ldots \ldots \ldots \ldots \ldots \ldots \ldots \ldots \ldots$ iii

Acronyms $\ldots \ldots \ldots \ldots \ldots \ldots \ldots \ldots \ldots \ldots \ldots \ldots \ldots \ldots \ldots \ldots \ldots \ldots \ldots$

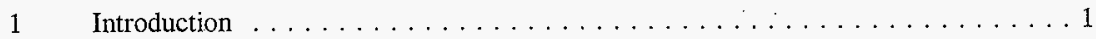

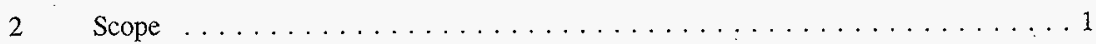

3 Organization Responsibilities and Authority $\ldots \ldots \ldots \ldots \ldots \ldots \ldots \ldots$

4 Quality Assurance Program Requirements . . . . . . . . . . . 2

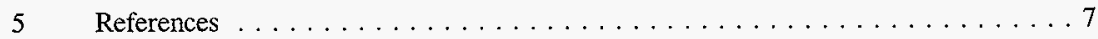

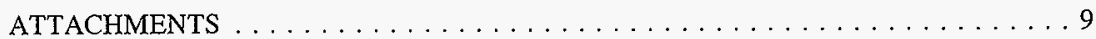

ATTACHMENT A

PROJECT CRITICAL CHARACTERISTICS $\ldots \ldots \ldots \ldots \ldots \ldots$

ATTACHMENT B

TYPES OF INDEPENDENT VERIFICATION AND INSPECTION $\ldots \ldots 12$

ATTACHMENT C

QUALITY ASSURANCE REQUIREMENTS MATRIX . . . . . . . 13

ATTACHMENT D

QAPD IMPLEMENTATION MATRIX ............. 22 
Acronyms

\begin{tabular}{|c|c|}
\hline $\mathrm{A}-\mathrm{E}$ & Architect-Engineering \\
\hline AI & Acceptance Inspection \\
\hline ASME & American Society of Mechanical Engineers \\
\hline BNFL & British Nuclear Fuels Limited, Incorporated \\
\hline $\mathrm{BR}$ & Basic Requirement [ $\ldots$ of ASME standard NQA-1] \\
\hline BWHC & $\mathrm{B} \& W$ Hanford Co. \\
\hline CFR & Code of Federal Regulation \\
\hline $\mathrm{CM}$ & Construction Management \\
\hline DOE-RL & Department of Energy, Richland Operations Office \\
\hline $\mathrm{ENCO}$ & Enterprise Company \\
\hline FDC & Functional Design Criteria \\
\hline $\mathrm{FDH}$ & Fluor Daniel Hanford \\
\hline FDNW & Fluor Daniel NorthWest \\
\hline GS & General Service \\
\hline MSC & Major Subcontractor \\
\hline NQA & Nuclear Quality Assurance \\
\hline $\mathrm{OC}$ & Operating Contractor \\
\hline PEP/PPM & Project Execution Plan/Project Procedures Manual \\
\hline PHMC & Project Hanford Management Contractor \\
\hline PHPP & Project Hanford Policies and Procedures \\
\hline PFP & Plutonium Finishing Plant \\
\hline PM & Project Management \\
\hline PMP & Project Management Plan \\
\hline PuSH & Plutonium Stabilization and Handling \\
\hline PSE & Preliminary Safety Evaluation \\
\hline PUSAP & Plutonium Stabilization and Packaging \\
\hline QA & Quality Assurance \\
\hline QAPD & Quality Assurance Program Description \\
\hline QAPP & Quality Assurance Program Plan \\
\hline SAR & Safety Analysis Report \\
\hline SC & Safety Class \\
\hline SPS & Stabilization and Packaging System \\
\hline SRID & Standards/Requirements Identification Document \\
\hline SS & Safety Significant \\
\hline SSC & Structures, Systems, and Components \\
\hline WBS & Work Breakdown Structure \\
\hline WHC & Westinghouse Hanford Company \\
\hline
\end{tabular}


1 Introduction

1.1 Project W-460, Plutonium Stabilization and Handling, encompasses several related actions which will implement the provisions of Department of Energy (DOE) Standard DOE-STD-3013-96 (3013) for special nuclear material inventories of plutonium and plutonium/uranium oxides at Hanford's Plutonium Finishing Plant (PFP), and will comply with the commitments of Defense Nuclear Facilities Safety Board Recommendation 94-1 to stabilize and package remaining plutonium by May 2002 for safe secure storage for up to fifty years. The Project will consolidate stabilization, packaging and storage functions into a single location within the PFP facility, the 2736$Z$ Complex. This will allow eventual deactivation of other PFP facility areas no longer needed while maintaining all functions required for safe storage. In addition to facility modifications to be designed, constructed and installed at the $2736-Z$ Storage Complex, the Project provides funding for a Stabilization and Packaging System (SPS) to be procured as part of a national procurement contract administered via the DOE Oakland Operations Office (DOE Contract DE-AC03-96SF20948, more commonly the PuSAP contract).

\section{Scope}

2.1 This Quality Assurance Program Plan (QAPP) identifies Project Quality Assurance (QA) program requirements for Fluor Daniel NorthWest (FDNW), an Enterprise Company (ENCO), and B\&W Hanford Co. (BWHC), a Major Subcontractor (MSC) under the Project Hanford Management Contractor (PHMC). This QAPP is prepared based upon the requirements identified in the PHMC Procedure, HNF-PRO-261, "Quality Assurance Program Plans" and shall be used as the consolidated QA Program document for BWHC and FDNW. These two contractors are involved in the planning and execution of Hanford Site activities for design, procurement, demolition, construction, installation, inspection and testing for Project W-460. These efforts are for the infrastructure that will be modified, fabricated, installed, and/or constructed in order to incorporate the new SPS in the 2736-Z Complex.

2.2 For new project related structures, systems, and components, other than the SPS equipment procurement, specific quality requirements will be incorporated into the definitive design media and procurement documents that will be prepared, approved and issued by FDNW and BWHC, as applicable, to subtier contractors and vendors. Procurement documents will incorporate those applicable quality requirements that are required to be passed down to design, fabricate, inspect, and/or test the procured structure, system, and/or component.

2.3 For the interfaces between the facility and the SPS, the quality requirements will be incorporated into the BWHC definitive design media to be used by onsite and/or subtier contractors.

2.4 For the SPS, the applicable quality requirements will be incorporated into the FDNW 
prepared procurement documents that DOE will be issuing for the SPS design, fabrication, and installation. As determined by BWHC Project Management, evaluations by BWHC and/or FDNW will be performed to ensure quality requirements have been incorporated into the SPS documentation.

\section{Organization Responsibilities and Authority}

3.1 BWHC, the Operating Contractor (OC) is responsible for overview of all quality related documentation for Project design, procurement, fabrication, installation, and construction, with exception of the SPS contract, unless assigned this responsibility by the Project Manager. This overview will ensure conformance with the requirements of the Functional Design Criteria (FDC) based upon approved OC procedures.

3.2 Responsible organizations performing Definitive Design Engineering, Engineering and Inspection during Construction, Procurement, Construction, and Project Management shall be identified within the confines of the Work Breakdown Structure (WBS) located in the Project Management Plan (PMP) prepared by the Project Manager. Specific responsibilities and interfaces are further defined in the PMP. If responsibilities are changed during the course of the project, these changes shall be made per approved $\mathrm{OC}$ procedures.

3.2.1 Fluor Daniel Hanford (FDH) Acceptance Inspection (AI) provides independent construction inspection for DOE-RL to verify and document the effectiveness of the construction project's quality control program. The Acceptance Inspection Plan identifies the required inspection events and $\mathrm{AI}$ hold points for the project. Acceptance Inspection performs the independent construction inspection/testing and source inspection/testing of construction workmanship, materials, and equipment for the purpose of evaluating conformity or nonconformity to the approved drawings and specifications. An Acceptance Inspection Plan will be required for the W-460 construction project. It is generated by FDH Acceptance Inspection and submitted to the DOE-RL Project Office for approval and subsequent transmittal to the BWHC Project Integrator prior to initiation of construction.

3.3 The Construction Contractor(s) and Vendor(s) are responsible and held accountable for their assigned work regarding project and procurement quality. The Construction Contractor and/or Vendor shall perform, or have performed, assigned quality verification activities as specified in procurement documents and identified in drawings, specifications and other approved Project documents.

4 Quality Assurance Program Requirements

4.1 Quality Assurance Program requirements are derived or based upon HNF-MP-599, "Project Hanford Quality Assurance Program Description" (QAPD), which defines the implementation of 10 CFR 830.120 and DOE Order 5700.6C. As this project affects a 
Nuclear Facility, the "Enforcement Applicability" of 10 CFR 830.120 is required and is addressed in the Forward of the QAPD. The ten basic sections of the QAPD form the foundation for the requirements for all quality assurance activities. Each of these QAPD sections are identified further in paragraph 4.7. Application of the quality assurance program is based on the graded approach as noted in paragraphs 4.3 and 4.4 . The Project Hanford Policy and Procedures (PHPP) are the site wide policy and procedures which are utilized for BWHC activities. The QAPD, PHPPs, company level procedures, facility level documents, and this project QAPP provide specific controls for work performance. The QAPD Implementation Matrix (Attachment D) identifies applicable implementing Project Hanford/BWHC procedures for performing work on Project W-460. References to FDNW procedures are also included in the matrix. Note that only minimal QA related procedures are identified. The remaining FDNW procedures to be used are identified and/or included in the FDNW Project Execution Plan/Project Procedures Manual. The applicability of these procedures is a selective process dependent upon the work being performed and the safety significance of the activities.

\subsection{Quality Assurance Requirements Flowdown}

Applicable QA requirements shall be passed down from BWHC to sub-tier contractors (FDNW and Construction Contractors) through statements of work, task orders, definitive design media, and/or procurement documents, as applicable. Further instruction as to the extent of QA requirements derived from the QAPD, and the implementation of these requirements, based upon a graded approach are noted in paragraphs $4.3,4.4$, and 4.6 .

\subsection{Application of the Graded Approach}

The quality management programs focus on the controls and systems necessary to ensure the output quality as required by 10 CFR 830.120 and DOE Order 5700.6C. Quality controls and systems will be applied to Project W-460 activities using a graded approach. The graded approach will be used to determine the scope and degree of rigor of the application of these requirements i.e., a process by which the level of analysis, level of documentation, level of verification and actions necessary to comply with requirements are defined. The graded application of the QA Program requirements will be achieved through an a varying combination of the following:

(1) The nuclear safety application of the item or activity.

(2) The level of risk and impact associated with a failure or deficiency.

(3) The age, status, and condition of a facility, process, or an item.

(4) The history of problems at a facility, with a process, or an item.

(5) The adequacy of existing controlling documentation.

(6) The complexity of products or activities involved.

(7) The control of potential project delays and cost if failures or deficiencies occur. 


\subsection{Exceptions to the QAPD}

No specific exceptions are taken to the requirements established by the QAPD, however, the applicability of elements of the QAPD, based upon a graded approach, has been identified in Attachment C, "Quality Assurance Requirements Matrix". Each of the QAPD, Part 2, Quality Management Processes, Implementing Requirements paragraphs identified within the QAPD have been evaluated for applicability to Project W-460 in five main areas: Project Management (PM) by BWHC, ArchitectEngineering (A-E) by FDNW, Construction Management (CM) by FDNW, Construction Contractor activities by FDNW and/or a Fixed Price Contractor, and the SPS Procurement by British Nuclear Fuel Limited (BNFL). In addition, applicable references to a national standard, American Society of Mechanical Engineers, Nuclear Quality Assurance (ASME NQA-1), have been identified in the matrix for assistance in invoking specific quality requirements. These evaluations are at a high level which will require further decision making based upon the applicable structure, system, or component's Safety Class, Safety Significant, or General Service designation. As such, the more explicit applicability to each QAPD paragraph will be made during the definitive design process.

\subsection{QAPD Implementation Matrix}

The QAPD Implementation Matrix (Attachment D) provides a roadmap from HNF-MP0599 (QAPD) requirements to selected Project Hanford Policy and Procedures, BWHC and FDNW procedures which may be utilized as part of the Project W-460 QAPP to perform applicable work activities. Application of PHPP, BWHC, and/or FDNW procedures will be based upon the type of work being performed and the safety significance of the work.

\subsection{Critical characteristics of products and safety classification}

As part of the safety analysis process, a preliminary safety evaluation (PSE), "Preliminary Safety Evaluation for Project W-460, Plutonium Stabilization and Handling (PuSH)," HNF-SD-W460-PSE-001, has been prepared for Project W-460. The PSE identifies critical structures, systems, and components (SSCs) which are important to the safety functions (safety class or safety significant) of the project. From the PSE; critical characteristics of the SSC's are identified which will receive more rigorous quality controls and appropriate quality codes and standards selected and applied (ie., application of graded approach). The critical characteristics will be incorporated into applicable design or operations documents, verified, inspected or tested as appropriate and results evaluated and documented.

\subsection{Elements of the Quality Assurance Program Description}

\subsubsection{Program}


Quality Assurance Programs (QAPs) shall be developed, implemented, and maintained where identified within contract documents such as: statements of work, task orders, procurement documents, and definitive design media.

Quality Assurance Program requirements for Project W-460 are to comply with applicable portions of QAPD Part 2, Section 1, "Program".

\subsubsection{Personnel Training and Qualifications}

Personnel shall be adequately trained and qualified to perform their assigned tasks.

Training and qualification program requirements for Project W-460 are to comply with applicable portions of QAPD, Part 2, Section 2, "Personnel Training and Qualification".

\subsubsection{Quality Improvement}

Management shall ensure quality improvement processes are instituted for the prevention and detection of quality problems.

Quality improvement processes established for Project W-460 are to comply with applicable portions of QAPD, Part 2, Section 3, "Quality Improvement".

\subsubsection{Documents and Records}

Documentation and records control processes shall be employed for documents which control quality affecting activities.

Documents and records generated, processed, and maintained for Project W-460 are to comply with applicable portions of QAPD Part 2, Section 4, "Documents and Records".

\subsubsection{Work Processes}

Work processes shall be established which are defined and controlled by written policies, plans, procedures, drawings, or other means to ensure the quality required for Project W-460.

Implementing procedures used on Project W-460 shall comply with applicable portions of QAPD Part 2, Section 5, "Work Processes".

\subsubsection{Design}

Design activities shall be adequately controlled so that structures, systems, and 
components meet the applicable requirements and performance criteria established for Project W-460.

Design processes instituted for Project W-460 shall comply with applicable portions of QAPD Part 2, Section 6, "Design".

\subsubsection{Procurement}

Procurement processes shall adequately ensure structures, systems, components, or other items and services procured meet the appropriate technical and quality requirements established for Project W-460.

Procurement processes established for Project W-460 shall comply with applicable portions of QAPD Part 2, Section 7, "Procurement".

\subsubsection{Inspection and Acceptance Testing}

Inspection and acceptance testing processes shall adequately ensure structures, systems, components, or other items procured, fabricated, or installed meet established design performance and quality requirements.

Processes for inspection and acceptance testing for Project W-460 shall comply with applicable portions of QAPD Part 2, Section 8, "Inspection and Acceptance Testing".

\subsubsection{Management Assessment}

Management assessment processes shall be established to adequately address the achievement of strategic goals and the meeting of applicable standards related to Project W-460.

Management assessment processes for Project W-460 shall comply with the applicable portions of QAPD Part 2, Section 9. "Management Assessment".

\subsubsection{Independent Assessment}

BWHC, FDNW and applicable sub-tier contractor personnel are responsible for cooperating with FDH independent assessment personnel in planning, preparation, and performance of assessments. BWHC and lower tier contractor management, as applicable, are responsible for promptly correcting problems found by independent assessments and ensuring corrective action is effective.

Independent assessment processes for Project W-460 shall comply with the applicable portions of QAPD Part 2, Section 10. "Independent Assessment". 
5 References

DNFSB, 1994, "Recommendation 94-1 to the Secretary of Energy, pursuant to 42 USC $\$ 2286$ a(5) Atomic Energy Act of 1954, as amended," Defense Nuclear Facilities Safety Board, Washington, D.C.

DOE, 1996b, "Stabilization and Packaging System," Contract DE-AC03-96SF20948 as amended, U. S. Department of Energy - Oakland Operations Office, Oakland, California.

DOE, 1996c, DOE-STD-3013-96, "Criteria for Safe Storage of Plutonium Metals and Oxides," U. S. Department of Energy, Washington, D.C.

DOE Order 4700.1, "DOE Project Management System," U. S. Department of Energy, Washington, D.C.

DOE Order 5700.6C, "Quality Assurance," U. S. Department of Energy, Washington, D.C.

FDH, 1998, Project Hanford Management Contract, "Project Hanford Policy and Procedure System Reference Map," HNF-MD-034, Revision 0, Fluor Daniel Hanford, Inc., Richland, Washington.

FDH, 1997, Project Hanford Management Contract, "Project Hanford Quality Assurance Program Description," HNF-MP-599, Revision 0, Fluor Daniel Hanford, Inc., Richland, Washington.

FDH, 1997, Project Hanford Management Contract, "Quality Assurance Program Plans," HNF-PRO-261, Revision 0, Fluor Daniel Hanford, Inc., Richland, Washington.

FDH, 1996, "Functional Design Criteria for Project W-460, Plutonium Stabilization and Handling (PuSH)," HNF-SD-W460-FDC-001, Revision 0, Fluor Daniel Hanford Company, Richland, Washington.

FDH, 1997, "Preliminary Safety Evaluation for Project W-460, Plutonium Stabilization and Handling (PuSH)," HNF-SD-W460-PSE-001, Revision 0, Fluor Daniel Hanford Company, Richland, Washington. 
FDNW, 1997, "Facility Stabilization Project Execution Plan and Project Procedures Manual," B\&W Hanford Company, Facility Stabilization Project, Contract 651002, Revision 0, Fluor Daniel NorthWest, Richland, Washington.

United States Code of Federal Regulations 10 CFR 830.120, "Nuclear Safety Management Quality Assurance," Washington, D.C.

WHC, 1994, "Plutonium Finishing Plant Standards/Requirements Identification Document," WHC-SD-MP-SRID-003, Westinghouse Hanford Company, Richland, Washington.

WHC, 1995, "Plutonium Finishing Plant Final Safety Analysis Report," WHC-SD-CP-SAR-021, Westinghouse Hanford Company, Richland, Washington. 


\section{ATTACHMENTS}


ATTACHMENT A

\section{PROJECT CRITICAL CHARACTERISTICS FOR PROJECT W-460, PUSH}

\begin{tabular}{|c|c|c|c|c|c|c|}
\hline \multirow{2}{*}{$\begin{array}{l}\text { ITEM } \\
\text { ID }\end{array}$} & \multirow{2}{*}{$\begin{array}{c}\text { STRUCTURE, SYSTEM, OR } \\
\text { COMPONENT **}\end{array}$} & \multirow{2}{*}{$\begin{array}{l}\text { PRELIM. SAFETY } \\
\text { CLASSIFICATION }\end{array}$} & \multicolumn{3}{|c|}{$\begin{array}{c}\text { TYPE OF } \\
\text { INSPECTION }\end{array}$} & \multirow[t]{2}{*}{ COMMENTS } \\
\hline & & & $\mathrm{F}$ & $\mathrm{G}$ & $\mathrm{D}$ & \\
\hline 1 & 2736-ZB Building Structure & $\mathrm{SC}$ & & & $\mathrm{X}$ & \\
\hline 2 & $2736-Z$ Building Structure & $\mathrm{SC}$ & & & $\mathrm{X}$ & \\
\hline 3 & $\begin{array}{l}2736-Z \text { Building Storage Cubicles and } \\
\text { Canister Holders }\end{array}$ & SC & & & $x$ & \\
\hline 4 & $\begin{array}{l}\text { SPS Glovebox Structure and Floor } \\
\text { Anchors }\end{array}$ & $\mathrm{SC}$ & & & $\mathrm{x}$ & $\begin{array}{l}\text { Design, fabrication and installation } \\
\text { criteria for the SPS shall be } \\
\text { designated in Procurement } \\
\text { Specification for DOE Contract. }\end{array}$ \\
\hline 5 & $\begin{array}{l}\text { SPS Exhaust System HEPA Filters, } \\
\text { HEPA Filter Housing and Ductwork } \\
\text { up to 2736-ZB Roof Penetration }\end{array}$ & $\mathrm{SC}$ & & & $X$ & \\
\hline 6 & $\begin{array}{l}2736-Z B \text { Building Final HEPA } \\
\text { Filters, HEPA Filter Housing, and } \\
\text { Ductwork up to HEPA Filter Housing }\end{array}$ & $S C$ & & & $x$ & \\
\hline 7 & $\begin{array}{l}2736-Z \text { Building exhaust System } \\
\text { HEPA Filters, HEPA Filter Housing, } \\
\text { and Ductwork up to HEPA Filter } \\
\text { Housing }\end{array}$ & $\mathrm{SC}$ & & & $X$ & \\
\hline 8 & $\begin{array}{l}\text { Vault Ventilation Supply Backdraft } \\
\text { Damper or Supply Filters }\end{array}$ & $\mathrm{SC}$ & & & $x$ & \\
\hline 9 & $\begin{array}{l}\text { Construction Door on East Wall of } \\
2736-Z B\end{array}$ & sC & & & $x$ & \\
\hline 10 & $\begin{array}{l}\text { Cutting Tools and Electrical } \\
\text { Equipment Inside the SPS Material } \\
\text { Preparation Area }\end{array}$ & $\mathrm{SC}$ & $\mathrm{x}$ & & & \\
\hline 11 & $\begin{array}{l}\text { Facility CAMs and Vault Air } \\
\text { Sampling System }\end{array}$ & SS & $x$ & & & \\
\hline 12 & $\begin{array}{l}\text { Furnace Cooling Jacket, IF Water } \\
\text { Cooling is used }\end{array}$ & SS & $x$ & & & \\
\hline 13 & $\begin{array}{l}\text { Moisture Detection in SPS } \\
\text { Gloveboxes }\end{array}$ & SS & $\mathrm{x}$ & & & \\
\hline 14 & Drier on SPS Supply Air & SS & $\mathrm{x}$ & & & \\
\hline 15 & Criticality Alarms & SS & $\mathrm{x}$ & & & \\
\hline
\end{tabular}


Rev. 0

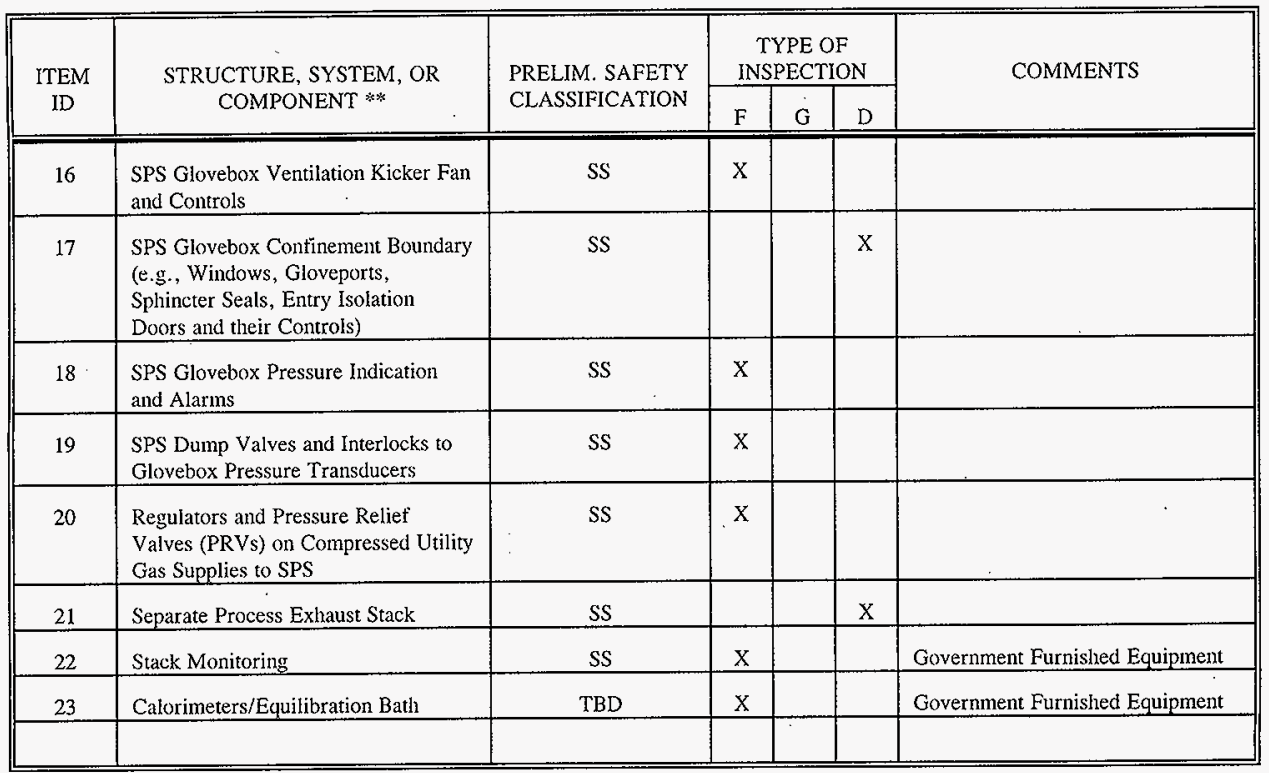

\section{LEGEND:}

$\begin{array}{lll}\text { D } & \text { Detailed (Inspection) } & \text { See Attachment B } \\ \text { F } & \text { Functional (Inspection) } & \text { See Attachment B } \\ \text { G } & \text { General (Inspection) } & \text { See Attachment B } \\ \text { GS } & \text { General Service } & \\ \text { SC } & \text { Safety Class } & \\ \text { SS } & \text { Safety Significant } & \\ \text { TBD } & \text { To Be Determined } & \end{array}$

\section{NOTES:}

1) ** Information based upon the SSC identified in the Preliminary Safety Evaluation, HNF-SD-W460-PSE-001, Rev. 0 .

2) Unless Specified Otherwise, Remaining Structures, Systems, and/or Components are considered as General Service (e.g., Robotics for Handling/Transport of 3013 Containers, Modular Office Trailer: Including Structural Components, Utilities, etc.) 


\section{ATTACHMENT B}

\section{TYPES OF INDEPENDENT VERIFICATION AND INSPECTION}

Specific rules covering all phases of inspection cannot be prescribed due to the variety and types of contracts and subcontracts, and the degree of responsibility assigned to the operating contractor, architect-engineer, construction contractors, and individual vendors. In general, inspection activities are divided into three categories: Functional, General and Detailed.

1. Functional Inspection. Performed to determine overall compliance with contract drawings and specifications. Functional Inspection may vary from inspection of minor items to extensive testing of operating equipment (which must be provided for in the contract). It may also serve in making initial determination of the adequacy of the design effort. The field element and the operating contractor participate in functional inspections from the viewpoints of owner and user.

2. General Inspection. The fundamental and comprehensive inspection to ascertain that workmanship and kind and quality of materials conform to the contract specifications.

3. Detailed Inspection. Includes, but is not limited to, verification of details, such as checking location and size of reinforcing bars, maintaining records of concrete batching operations, verifying the use of proper welding rods, checking riveting and welding, and performing other inspection for quality assurance purposes. Detailed inspections are carried out from initial construction operations and extend through all construction stages. 
ATT ACHMENT C

QUALITY ASSURANCE REQUIREMENTS MATRIX

\begin{tabular}{|c|c|c|c|c|c|c|c|}
\hline \multirow{3}{*}{\multicolumn{2}{|c|}{$\begin{array}{c}\text { HNF-MP-599 } \\
\text { QAPD } \\
\text { Part } 2 \\
\text { Requirements by Paragraph } \\
\text { Including Keywords }\end{array}$}} & \multirow{3}{*}{$\begin{array}{l}\text { Related } \\
\text { Standard } \\
\text { NQA-1 }\end{array}$} & \multicolumn{5}{|c|}{ PROJECT PARTICIPANTS } \\
\hline & & & \multirow[t]{2}{*}{$\begin{array}{c}\text { PM } \\
\text { BWHC }\end{array}$} & \multirow[t]{2}{*}{$\begin{array}{c}\text { A-E } \\
\text { FDNW }\end{array}$} & \multirow[t]{2}{*}{$\begin{array}{c}\mathrm{CM} \\
\text { FDNW }\end{array}$} & $\begin{array}{l}\text { Construction } \\
\text { Contractor }\end{array}$ & \multirow{2}{*}{$\begin{array}{c}\text { SPS } \\
\text { Procurement } \\
\text { BNFL }\end{array}$} \\
\hline & & & & & & $\begin{array}{l}\text { FDNW/Fixed } \\
\text { Price } \\
\end{array}$ & \\
\hline \multicolumn{8}{|c|}{ SECTION 1} \\
\hline $3.1 * *$ & Structure, QA Program & & & & & & \\
\hline 3.2 & QA Procedures & & $\checkmark$ & & & & \\
\hline 3.3 .1 & \multirow[t]{5}{*}{ QA Program Plans } & & $\checkmark$ & & & & \\
\hline 3.3 .2 & & $\begin{array}{c}\text { Basic } \\
\text { Requirement } \\
(B R) 2 \\
\end{array}$ & $\checkmark$ & $\checkmark$ & $\checkmark$ & $\checkmark$ & \\
\hline 3.3 .3 & & & $\checkmark$ & $\checkmark$ & $\checkmark$ & $\checkmark$ & $\checkmark$ \\
\hline \multicolumn{7}{|l|}{$3.3 .4^{* *}$} & \\
\hline 3.3 .5 & & & $\checkmark$ & $\checkmark$ & $\checkmark$ & $\checkmark$ & $\checkmark$ \\
\hline $3.4 .1 * \%$ & \multirow[t]{2}{*}{ QA Requirements Flowdown } & & & & & & \\
\hline 3.4 .2 & & & $\checkmark$ & $\checkmark$ & $\checkmark$ & $\checkmark$ & $\checkmark$ \\
\hline 3.5 & Quality Planning & & $\checkmark$ & & & & \\
\hline 3.6 .1 & \multirow[t]{3}{*}{ Organization, Responsibilities, Interfaces } & BR 1 & $\checkmark$ & $\checkmark$ & $\checkmark$ & $\checkmark$ & $\checkmark$ \\
\hline 3.6 .2 & & $1 S-12.1$ & $\checkmark$ & $\checkmark$ & $\checkmark$ & $\checkmark$ & $\checkmark$ \\
\hline 3.6 .3 & & $1 S-13.2$ & $\checkmark$ & & & & \\
\hline 3.7 & Readiness Review & & $\checkmark$ & & & & \\
\hline
\end{tabular}




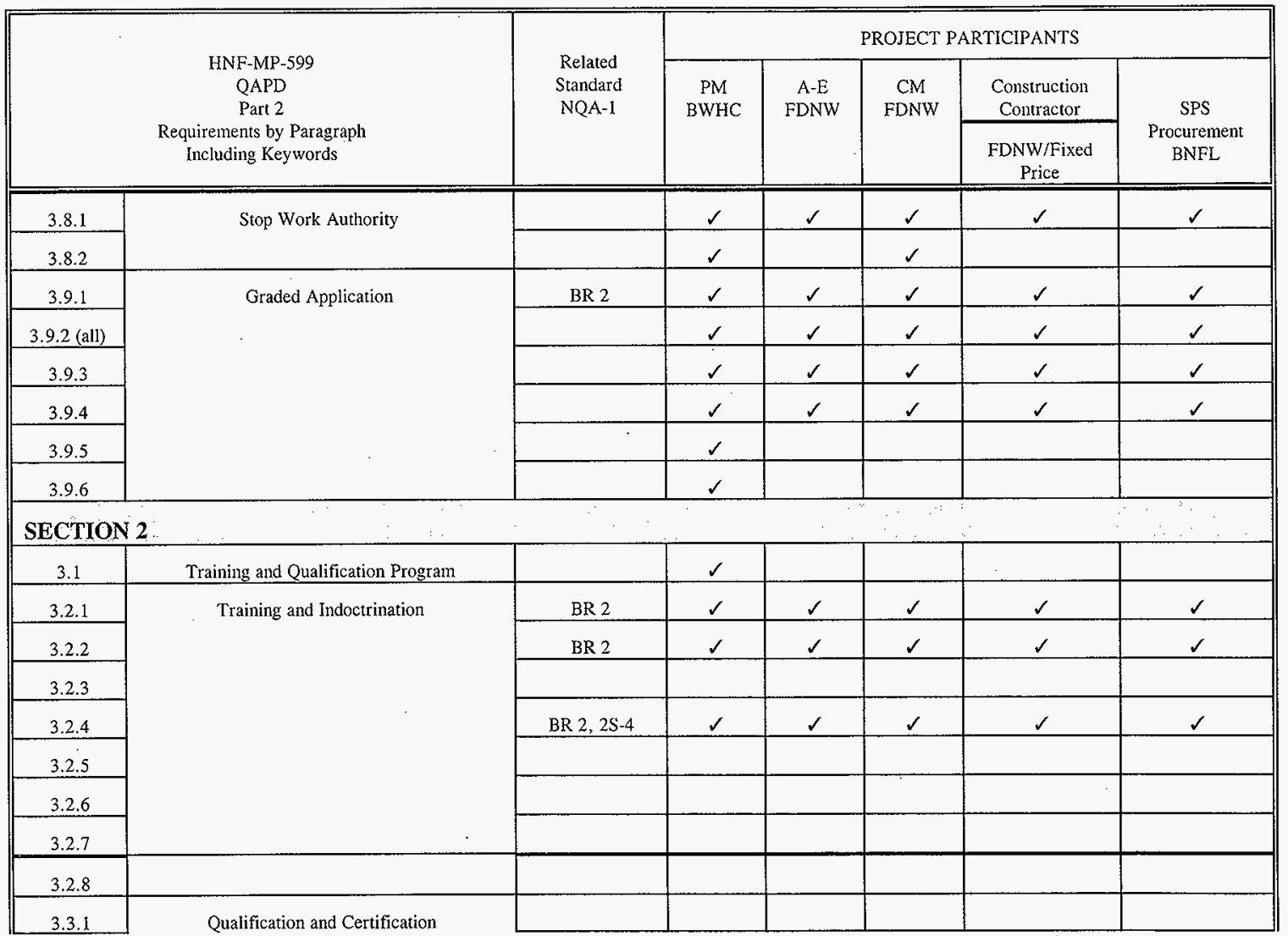




\begin{tabular}{|c|c|c|c|c|c|c|c|}
\hline & \multirow{3}{*}{$\begin{array}{c}\text { HNF-MP-599 } \\
\text { QAPD } \\
\text { Part } 2 \\
\text { Requirements by Paragraph } \\
\text { Including Keywords }\end{array}$} & \multirow{3}{*}{$\begin{array}{l}\text { Related } \\
\text { Standard } \\
\text { NQA-1 }\end{array}$} & \multicolumn{5}{|c|}{ PROJECT PARTICIPANTS } \\
\hline & & & \multirow[t]{2}{*}{$\begin{array}{c}\text { PM } \\
\text { BWHC }\end{array}$} & \multirow[t]{2}{*}{$\begin{array}{c}\text { A-E } \\
\text { FDNW }\end{array}$} & \multirow[t]{2}{*}{$\begin{array}{c}\text { CM } \\
\text { FDNW }\end{array}$} & $\begin{array}{c}\text { Construction } \\
\text { Contractor }\end{array}$ & \multirow{2}{*}{$\begin{array}{c}\text { SPS } \\
\text { Procurement } \\
\text { BNFL }\end{array}$} \\
\hline & & & & & & $\begin{array}{l}\text { FDNW/Fixed } \\
\text { Price } \\
\end{array}$ & \\
\hline 3.3 .2 & & & $\checkmark$ & $\checkmark$ & $\checkmark$ & $\checkmark$ & $\checkmark$ \\
\hline 3.3 .3 & & $2 S-1,2 S-22.3$ & & $\checkmark$ & & $\checkmark$ & $\checkmark$ \\
\hline 3.3 .4 & & $2 S-12.1$ & & $\checkmark$ & & $\checkmark$ & $\checkmark$ \\
\hline 3.4 & Training and Qualification Records & & $\checkmark$ & $\checkmark$ & $\checkmark$ & $\checkmark$ & $\checkmark$ \\
\hline \multicolumn{8}{|c|}{ SECTION 3} \\
\hline 3.1 .1 & \multirow[t]{2}{*}{ Deficiency Identification } & BR 16 & $\checkmark$ & $\checkmark$ & $\checkmark$ & $\checkmark$ & $\checkmark$ \\
\hline 3.1 .2 & & & & & & & \\
\hline 3.2 .1 & \multirow[t]{2}{*}{ Corrective Action Management } & BR 16 & $\checkmark$ & $\checkmark$ & $\checkmark$ & $\checkmark$ & \\
\hline 3.2 .2 & & BR 16 & $\checkmark$ & $\checkmark$ & $\checkmark$ & $\checkmark$ & \\
\hline 3.3 .1 & \multirow[t]{6}{*}{ Nonconformance Control } & $\begin{array}{l}\text { BR } 15,15 S-1 \\
4.1,1 S-12.3\end{array}$ & $\checkmark$ & & $\checkmark$ & $\checkmark$ & $\checkmark$ \\
\hline 3.3 .2 & & & & & $\checkmark$ & $\checkmark$ & $\checkmark$ \\
\hline 3.3 .3 & & $15 \mathrm{~S}-12(\mathrm{a})$ & & & $\checkmark$ & $\checkmark$ & $\checkmark$ \\
\hline 3.3 .4 & & $15 \mathrm{~S}-13$ & & & $\checkmark$ & $\checkmark$ & $\checkmark$ \\
\hline 3.3 .5 & & $15 \mathrm{~S}-14.3$ & $\checkmark$ & $\checkmark$ & $\checkmark$ & $\checkmark$ & $\checkmark$ \\
\hline 3.3 .6 & & $15 S-14.4$ & & $\checkmark$ & $\checkmark$ & $\checkmark$ & $\checkmark$ \\
\hline 3.3 .7 & & $15 \mathrm{~S}-14.5$ & & & $\checkmark$ & $\checkmark$ & $\checkmark$ \\
\hline 3.3 .8 & & & & & $\checkmark$ & $\checkmark$ & $\checkmark$ \\
\hline 3.3 .9 & & & & & $\checkmark$ & $\checkmark$ & $\checkmark$ \\
\hline
\end{tabular}




\begin{tabular}{|c|c|c|c|c|c|c|c|}
\hline & \multirow{3}{*}{$\begin{array}{c}\text { HNF-MP-599 } \\
\text { QAPD } \\
\text { Part } 2 \\
\text { Requirements by Paragraph } \\
\text { Including Keywords }\end{array}$} & \multirow{3}{*}{$\begin{array}{c}\text { Related } \\
\text { Standard } \\
\text { NQA-1 }\end{array}$} & \multicolumn{5}{|c|}{ PROJECT PARTICIPANTS } \\
\hline & & & \multirow[t]{2}{*}{$\begin{array}{c}\text { PM } \\
\text { BWHC }\end{array}$} & \multirow[t]{2}{*}{$\begin{array}{c}\text { A-E } \\
\text { FDNW }\end{array}$} & \multirow[t]{2}{*}{$\begin{array}{c}\text { CM } \\
\text { FDNW }\end{array}$} & $\begin{array}{l}\text { Construction } \\
\text { Contractor }\end{array}$ & \multirow{2}{*}{$\begin{array}{c}\text { SPS } \\
\text { Procurement } \\
\text { BNFL }\end{array}$} \\
\hline & & & & & & $\begin{array}{l}\text { FDNW/Fixed } \\
\text { Price }\end{array}$ & \\
\hline $3.4 .1 * *$ & \multirow[t]{6}{*}{ Performance Data Analysis } & & & & & & \\
\hline & & \multicolumn{6}{|c|}{$3.4 .2 * *$} \\
\hline \multicolumn{7}{|l|}{$3.4 .3 * *$} & \\
\hline 3.4 .4 & & BR 16 & $\checkmark$ & & & & \\
\hline 3.4 .5 & & & $\checkmark$ & & & & \\
\hline 3.4 .6 & & BR 16 & $r$ & & & & \\
\hline \multicolumn{8}{|c|}{ SECTION 4} \\
\hline 3.0 & Documents and Records & & $\checkmark$ & & & & \\
\hline 3.1 .1 & \multirow[t]{5}{*}{ Documents } & $6 \mathrm{~S}-12$ & $\checkmark$ & $\checkmark$ & $\checkmark$ & $\checkmark$ & $\checkmark$ \\
\hline 3.1 .2 & & $\mathrm{BR} 6$ & $\checkmark$ & $\checkmark$ & $\checkmark$ & $\checkmark$ & $\checkmark$ \\
\hline 3.1 .3 & & BR 6 & $\checkmark$ & $\checkmark$ & $\checkmark$ & $\checkmark$ & $\checkmark$ \\
\hline 3.1 .4 & & $6 S-13$ & $\checkmark$ & $\checkmark$ & $\checkmark$ & $\checkmark$ & $\checkmark$ \\
\hline 3.1 .5 & & & & $\checkmark$ & & & \\
\hline
\end{tabular}


HNF-SD-W460-QAPP-001

Rev. 0

\begin{tabular}{|c|c|c|c|c|c|c|c|}
\hline & \multirow{3}{*}{$\begin{array}{c}\text { HNF-MP-599 } \\
\text { QAPD } \\
\text { Part } 2 \\
\text { Requirements by Paragraph } \\
\text { Including Keywords }\end{array}$} & \multirow{3}{*}{$\begin{array}{l}\text { Related } \\
\text { Standard } \\
\text { NQA-1 }\end{array}$} & \multicolumn{5}{|c|}{ PROJECT PARTICIPANTS } \\
\hline & & & \multirow[t]{2}{*}{$\begin{array}{c}\text { PM } \\
\text { BWHC }\end{array}$} & \multirow[t]{2}{*}{$\begin{array}{c}\text { A-E } \\
\text { FDNW }\end{array}$} & \multirow[t]{2}{*}{$\begin{array}{c}\text { CM } \\
\text { FDNW }\end{array}$} & $\begin{array}{l}\text { Construction } \\
\text { Contractor }\end{array}$ & \multirow{2}{*}{$\begin{array}{c}\text { SPS } \\
\text { Procurement } \\
\text { BNFL }\end{array}$} \\
\hline & & & & & & $\begin{array}{c}\text { FDNW/Fixed } \\
\text { Price }\end{array}$ & \\
\hline 3.2 .1 & \multirow[t]{5}{*}{ Records } & BR 17 & 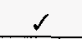 & $\checkmark$ & $\checkmark$ & $s$ & $\checkmark$ \\
\hline 3.2 .2 & & & & & $\checkmark$ & $\checkmark$ & $\checkmark$ \\
\hline 3.2 .3 & & $\begin{array}{c}17 \mathrm{~S}-1,2.8,2.9 \\
4,5 \\
\end{array}$ & $\checkmark$ & $\checkmark$ & $\checkmark$ & $\checkmark$ & $\checkmark$ \\
\hline 3.2 .4 & & & $\checkmark$ & & & & \\
\hline 3.2 .5 & & & & $\checkmark$ & & $\checkmark$ & $\checkmark$ \\
\hline \multicolumn{8}{|c|}{ SECTION 5} \\
\hline 3.1 .1 & \multirow[t]{5}{*}{ Work Process Documents } & BR 5 & $\checkmark$ & $\checkmark$ & $\checkmark$ & $\checkmark$ & $\checkmark$ \\
\hline 3.1 .2 & & & & $d$ & $\checkmark$ & $\checkmark$ & $\checkmark$ \\
\hline 3.1 .3 & & & & & $\checkmark$ & $\checkmark$ & $\checkmark$ \\
\hline 3.1 .4 & & & & $\checkmark$ & $\checkmark$ & $\checkmark$ & $\checkmark$ \\
\hline 3.1 .5 & & & & $\checkmark$ & $\alpha$ & $\checkmark$ & $\checkmark$ \\
\hline 3.2 & Special Processes & BR 9 & & & & $\checkmark$ & $\checkmark$ \\
\hline 3.3 .1 & \multirow[t]{3}{*}{ Identification and Control of Items } & BR $8,8 \mathrm{~S}-13.1$ & & & $\checkmark$ & $\checkmark$ & $\checkmark$ \\
\hline 3.3 .2 & & BR 14 & & & $\checkmark$ & $\checkmark$ & $\checkmark$ \\
\hline 3.3 .3 & & $8 \mathrm{~S}-12.3$ & & & $\checkmark$ & $\checkmark$ & $\checkmark$ \\
\hline
\end{tabular}




\begin{tabular}{|c|c|c|c|c|c|c|c|}
\hline & \multirow{3}{*}{$\begin{array}{l}\text { HNF-MP-599 } \\
\text { QAPD } \\
\text { Part } 2 \\
\text { Requirements by Paragraph } \\
\text { Including Keywords }\end{array}$} & \multirow{3}{*}{$\begin{array}{l}\text { Related } \\
\text { Standard } \\
\text { NQA-1 }\end{array}$} & \multicolumn{5}{|c|}{ PROJECT PARTICIPANTS } \\
\hline & & & \multirow[t]{2}{*}{$\begin{array}{c}\text { PM } \\
\text { BWHC }\end{array}$} & \multirow[t]{2}{*}{$\begin{array}{l}\text { A-E } \\
\text { FDNW }\end{array}$} & \multirow[t]{2}{*}{$\begin{array}{l}\text { CM } \\
\text { FDNW }\end{array}$} & $\begin{array}{l}\text { Construction } \\
\text { Contractor }\end{array}$ & \multirow{2}{*}{$\begin{array}{c}\text { SPS } \\
\text { Procurement } \\
\text { BNFL }\end{array}$} \\
\hline & & & & & & $\begin{array}{l}\text { FDNW/Fixed } \\
\text { Price }\end{array}$ & \\
\hline 3.4 .1 & \multirow[t]{3}{*}{ Handling, Shipping, and Storing } & BR 13 & & & $\checkmark$ & $\checkmark$ & $\checkmark$ \\
\hline 3.4 .2 & & $13 S-12$ & & & $\checkmark$ & $\checkmark$ & $\checkmark$ \\
\hline 3.4 .3 & & $13 S-14$ & & & $\checkmark$ & $\checkmark$ & $\checkmark$ \\
\hline 3.5 & $\begin{array}{l}\text { Process Monitoring or Data Collection } \\
\text { Instruments }\end{array}$ & BR 12 & & $\checkmark$ & & $\checkmark$ & $\checkmark$ \\
\hline 3.6 & Control of Computer Software & $11 S-2$ & $\checkmark$ & $\checkmark$ & $\checkmark$ & $\checkmark$ & $\checkmark$ \\
\hline \multicolumn{8}{|c|}{ SECTION 6} \\
\hline 3.1 & \multirow[t]{4}{*}{ Design Input } & & $\checkmark$ & $\checkmark$ & & . & $\checkmark$ \\
\hline 3.1 .1 & & BR 3, 3S-1 2 & $\checkmark$ & $\checkmark$ & & & $\checkmark$ \\
\hline 3.1 .2 & & BR 3 & $\checkmark$ & $\checkmark$ & & & $\checkmark$ \\
\hline 3.1 .3 & & $3 S-12$ & $\checkmark$ & $\checkmark$ & & & $\checkmark$ \\
\hline 3.2 .1 & \multirow[t]{7}{*}{ Design Process } & & & $\checkmark$ & & & $\checkmark$ \\
\hline 3.2 .2 & & & & $\checkmark$ & & & $\checkmark$ \\
\hline 3.2 .3 & & $3 S-16$ & & $\checkmark$ & & & $\checkmark$ \\
\hline 3.2 .4 & & & $\checkmark$ & & & & \\
\hline 3.2 .5 & & $3 S-16$ & $\checkmark$ & $\checkmark$ & $\checkmark$ & $\checkmark$ & $\checkmark$ \\
\hline 3.2 .6 & & & $\checkmark$ & $\checkmark$ & & & $\checkmark$ \\
\hline 3.2 .7 & & $3 \mathrm{~S}-13$ & & $\checkmark$ & & & $\checkmark$ \\
\hline 3.2 .8 & $(\operatorname{con} ' t)$ Design Process & $3 \mathrm{~S}-13.1$ & & $\checkmark$ & & & $\checkmark$ \\
\hline
\end{tabular}


HNF-SD-W460-QAPP-001

Rev. 0

\begin{tabular}{|c|c|c|c|c|c|c|c|}
\hline & \multirow{3}{*}{$\begin{array}{c}\text { HNF-MP-599 } \\
\text { QAPD } \\
\text { Part } 2 \\
\text { Requirements by Paragraph } \\
\text { Including Keywords }\end{array}$} & \multirow{3}{*}{$\begin{array}{l}\text { Related } \\
\text { Standard } \\
\text { NQA-1 }\end{array}$} & \multicolumn{5}{|c|}{ PROJECT PARTICIPANTS } \\
\hline & & & \multirow{2}{*}{$\begin{array}{c}\text { PM } \\
\text { BWHC }\end{array}$} & \multirow[t]{2}{*}{$\begin{array}{c}\text { A-E } \\
\text { FDNW }\end{array}$} & \multirow[t]{2}{*}{$\begin{array}{c}\text { CM } \\
\text { FDNW }\end{array}$} & \multirow{2}{*}{$\begin{array}{c}\text { Construction } \\
\text { Contractor } \\
\text { FDNW/Fixed } \\
\text { Price } \\
\end{array}$} & \multirow{2}{*}{$\begin{array}{c}\text { SPS } \\
\text { Procurement } \\
\text { BNFL }\end{array}$} \\
\hline & & & & & & & \\
\hline 3.2 .9 & & $3 S-13.1$ & & $\checkmark$ & & & $\checkmark$ \\
\hline 3.2 .10 & & & & $\checkmark$ & & & $\checkmark$ \\
\hline 3.2 .11 & & & & $\checkmark$ & & & $\checkmark$ \\
\hline 3.3 .1 & Design Verification & $3 S-14.2$ & & $\checkmark$ & & & $\checkmark$ \\
\hline 3.3 .2 & & $3 S-14$ & & $\checkmark$ & & & $\checkmark$ \\
\hline 3.3 .3 & & BR 3, 3S-14 & & $\checkmark$ & & & $\checkmark$ \\
\hline 3.3 .4 & & $3 S-14.1$ & & $\checkmark$ & & & $\checkmark$ \\
\hline 3.4 .1 & Design Changes & BR 3, 3S-15 & $\checkmark$ & $\checkmark$ & $\checkmark$ & $\checkmark$ & $\checkmark$ \\
\hline 3.4 .2 & & & $\checkmark$ & $\checkmark$ & $\checkmark$ & $\checkmark$ & $\checkmark$ \\
\hline 3.5 & Design Documentation and Records & $3 S-17$ & $\checkmark$ & $\therefore$ & & & $\checkmark$ \\
\hline 3.6 & Computer Software & $3 S-13.1$ & $\checkmark$ & $\checkmark$ & & $\checkmark$ & $\checkmark$ \\
\hline SECTI & $\begin{array}{c}\therefore \\
\therefore\end{array}$ & & $\because$ & & & & \\
\hline 3.1 & Procurement Planning & $7 S-1$ & $\checkmark$ & $\checkmark$ & $\checkmark$ & $\checkmark$ & $\checkmark$ \\
\hline 3.2 .1 & Content of Procurement Documents & $4 S-12$ & $\checkmark$ & $\checkmark$ & $\checkmark$ & $\checkmark$ & $\checkmark$ \\
\hline 3.2 .2 & & $4 S-13$ & $\checkmark$ & $\checkmark$ & $\checkmark$ & $\checkmark$ & $\checkmark$ \\
\hline 3.2 .3 & & $7 S-17,4 S-14$ & $\checkmark$ & $\checkmark$ & $\checkmark$ & $\checkmark$ & $\checkmark$ \\
\hline
\end{tabular}


HNF-SD-W460-QAPP-001

Rev. 0

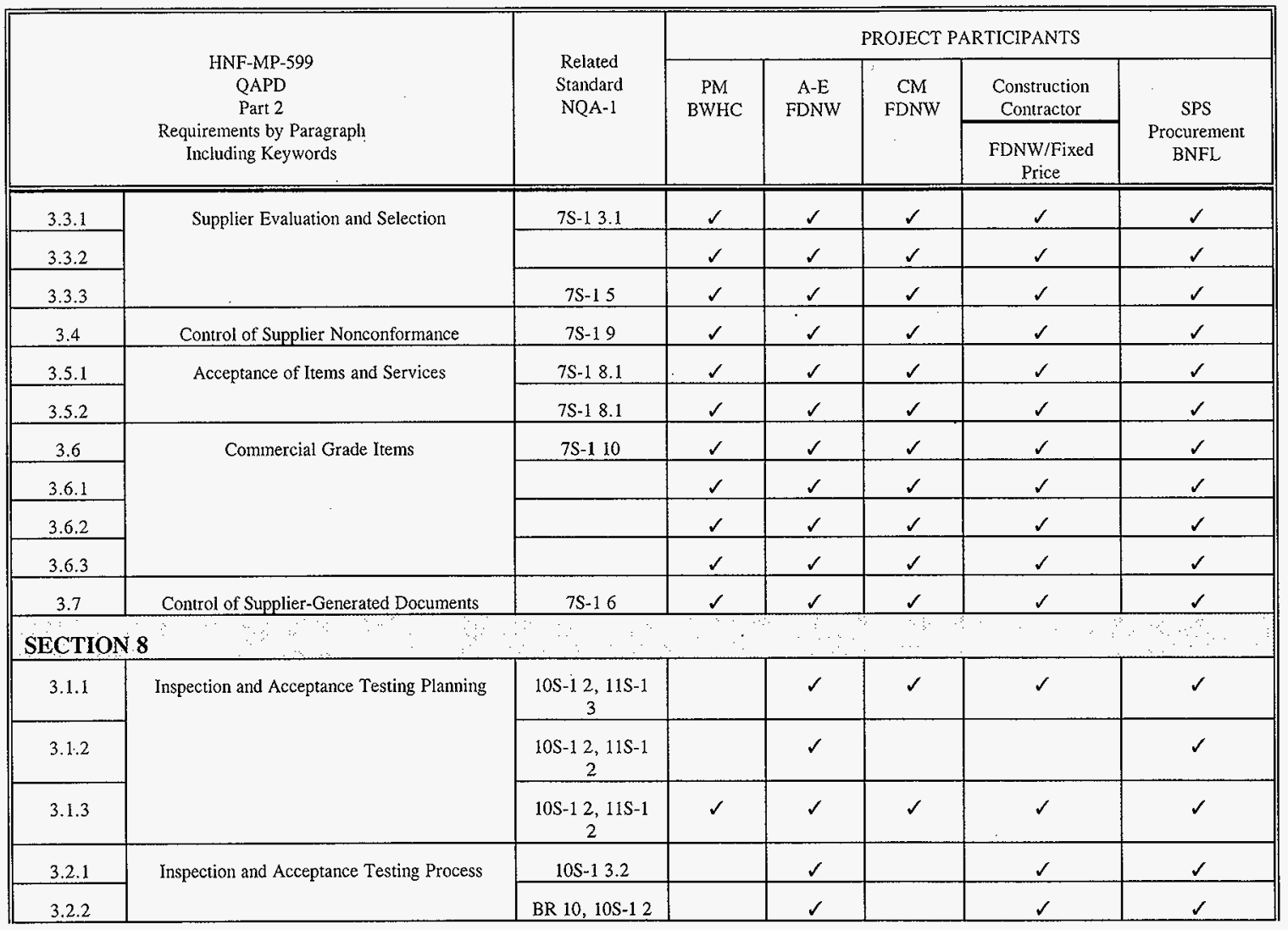


HNF-SD-W460-QAPP-001

Rev. 0

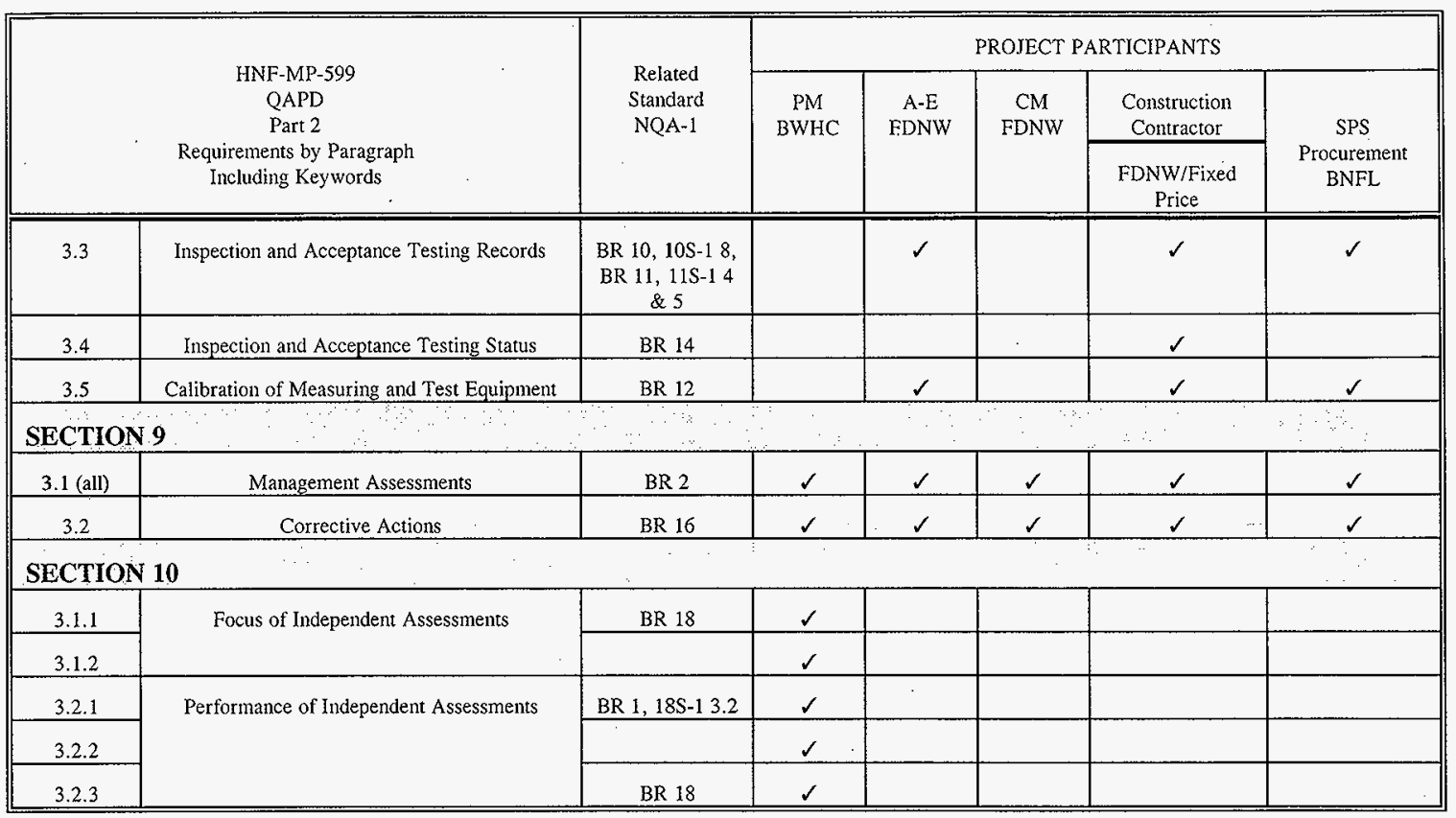

\section{Notes:}

1) Paragraph references which are missing from Matrix have been determined to not have applicable requirements, hence they have been eliminated.

2) Items identified with "**" have been determined to apply at a higher level and will not apply at the Project level.

3) Related Standard (NQA-1) is to be used as a Guide for applying the specific QAPD paragraph reference.

4) The use of the Matrix is as a Guide towards applying Quality Requirements to Safety Class Items. The Graded Approach shall be used for these feanures, as determined by the particular structure, system, or component involved. Further evaluation by a Graded Approach is to be used when evaluating Quality Requirements to be applied to Safety Significant or General Service structures, systems, or components. 


\section{ATTACHMENT D \\ QAPD IMPLEMENTATION MATRIX}

NOTE: This implementation matrix is based on a cross-reference between the Controlled Manual (CM) System and the Project Hanford Policy and Procedure (PHPP) System (ref.: HNF-MD-034, Project Hanford Policy and Procedure System Reference Map). This cross-reference is referred to as the CM-Map. The procedures in this matrix may change; therefore, it may be necessary for the user of this document to check the accuracy of these references, as this listing is not all-inclusive. Several Quality Assurance specific Contractor Procedures (FDNW) have been identified; for more complete information, it may be necessary for the user of this document to review the BWHC Contract 651002 , Facility Stabilization Project, Project Execution Plan/Project Procedures Manual.

\begin{tabular}{|c|c|c|}
\hline \multicolumn{3}{|c|}{ QAPD IMPLEMENTATION MATRIX } \\
\hline \multirow{2}{*}{ PROJECT HANFORD QAPD PART 2} & \multicolumn{2}{|c|}{ IMPLEMENTING PROCEDURES } \\
\hline & Project Hanford Procedures & Contractor Procedures \\
\hline $\begin{array}{l}\text { SECTION 1,PROGRAM } \\
\text { Quality Assurance Program Plans } \\
\text { Project Hanford QA Requirements Flowdown } \\
\text { Quality Planning } \\
\text { Organization, Responsibilities, and Interfaces } \\
\text { Readiness Reviews } \\
\text { Stop Work·Authority } \\
\text { Graded Application of Project Hanford QA } \\
\text { Program }\end{array}$ & $\begin{array}{ll}\text { HNF-PRO-055, } & \text { Startup and Restart of Facilities } \\
\text { HNF-PRO-261, } & \text { Quality Assurance Program Plans } \\
\text { HNF-PRO-704, } & \text { Hazard and Accident Analysis Process } \\
& \\
\text { FDH-MD-035, } & \text { Shutdown and Stop-Work Direction }\end{array}$ & 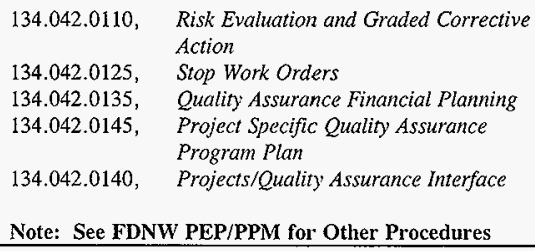 \\
\hline $\begin{array}{l}\text { SECTION 2, PERSONNEL TRAINING AND } \\
\text { QUALIFICATION } \\
\text { Project Hanford Training and Qualification } \\
\text { Program } \\
\text { Training and Indoctrination } \\
\text { Qualification and Certification } \\
\text { Training and Qualification Records } \\
\end{array}$ & 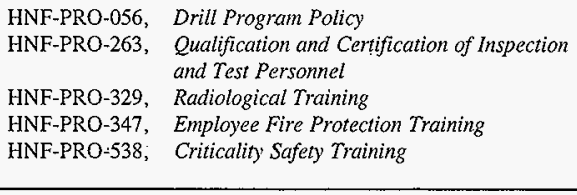 & $\begin{array}{ll}134.042 .0032, & \begin{array}{l}\text { Training/Qualification of Audit and } \\
\text { Surveillance Personnel }\end{array} \\
134.042 .0160, & \begin{array}{l}\text { Qualification of Quality Engineer } \\
\text { Personnel }\end{array}\end{array}$ \\
\hline
\end{tabular}




\begin{tabular}{|c|c|c|}
\hline \multicolumn{3}{|c|}{ QAPD IMPLEMENTATION MATRIX } \\
\hline \multirow[t]{2}{*}{ PROJECT HANFORD QAPD PART 2} & \multicolumn{2}{|c|}{ IMPLEMENTING PROCEDURES } \\
\hline & Project Hanford Procedures & Contractor Procedures \\
\hline $\begin{array}{l}\text { SECTION 3, QUALITY IMPROVEMENT } \\
\text { Deficiency Identification } \\
\text { Corrective Action Management } \\
\text { Nonconformance Control } \\
\text { Performance Data Analysis } \\
\text { Control of Suspect/Counterfeit Items }\end{array}$ & $\begin{array}{ll}\text { HNF-PRO-006, Identifying/Reporting a DOE Nuclear Safety } & \begin{array}{l}\text { Requirement Noncompliance } \\
\text { HNF-PRO-052, }\end{array} \\
\text { HNF-PRO-058, } & \text { Critique Procedure } \\
\text { HNF-PRO-060, Reporting Occurrences and Processing } & \text { Operations Information } \\
\text { HNF-PRO-063, Deficiency Tracking System } \\
\text { HNF-PRO-298, Nonconforming Item Reporting and Control } \\
\text { HNF-PRO-301, Control of Suspect/Counterfeit Items }\end{array}$ & 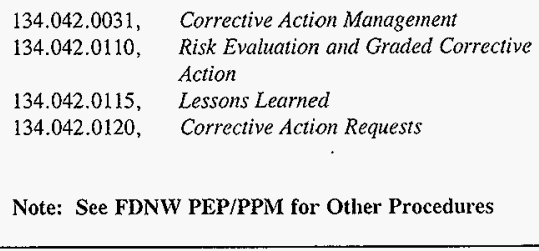 \\
\hline $\begin{array}{l}\text { SECTION 4, DOCUMENTS AND RECORDS } \\
\text { Documents } \\
\text { Records }\end{array}$ & $\begin{array}{ll}\text { HNF-PRO-208, } & \text { Records Management - General } \\
\text { HNF-PRO-210, } & \text { Records Management Program } \\
\text { HNF-PRO-214, Record Inventory and Disposition Schedules } \\
\text { HNF-PRO-222, Quality Assurance Records } \\
\text { HNF-PRO-224, Document Control } \\
\text { HNF-PRO-232, } \\
\text { HNF-PRO-233, } & \text { Review and Task Document Management } \\
\text { HNF-PRO-460, } & \text { Software Document Control } \\
\end{array}$ & $\begin{array}{l}\text { 134.042.0185, Inspection Document Reviews } \\
134.042 .0190, \quad \text { Final Acceptance Review } \\
000.100 .1212, \quad \text { Project Close-out } \\
\text { Note: See FONW PEP/PPM for Other Procedures }\end{array}$ \\
\hline
\end{tabular}




\begin{tabular}{|c|c|c|}
\hline \multicolumn{3}{|c|}{ QAPD IMPLEMENTATION MATRIX } \\
\hline \multirow[t]{2}{*}{ PROJECT HANFORD QAPD PART 2} & \multicolumn{2}{|c|}{ IMPLEMENTING PROCEDURES } \\
\hline & Project Hanford Procedures & Contractor Procedures \\
\hline $\begin{array}{l}\text { SECTION 5, WORK PROCESSES } \\
\text { Work Process Documents } \\
\text { Identification and Control of Items } \\
\text { Handling, Shipping, and Storing }\end{array}$ & $\begin{array}{ll}\text { HNF-PRO-062, } & \begin{array}{l}\text { Identifying and Resolving Unreviewed Safety } \\
\text { Questions }\end{array} \\
\text { HNF-PRO-072, } & \begin{array}{l}\text { Plant Instrumentation and Equipment Status } \\
\text { Labeling }\end{array} \\
\text { HNF-PRO-129, } & \begin{array}{l}\text { Controlling Spare Parts and Spare Equipment } \\
\text { Inventory }\end{array} \\
\text { HNF-PRO-134, } & \begin{array}{l}\text { Identifying and Controlling Materials, Parts } \\
\text { and Components }\end{array} \\
\text { HNF-PRO-135, } & \begin{array}{l}\text { Receiving, Inspection, Storage, Issuance and } \\
\text { Return of Contractor Procured ASME Code }\end{array} \\
\text { HNF-PRO-229, } & \begin{array}{l}\text { Material } \\
\text { Technical Procedure Standard }\end{array} \\
\text { HNF-PRO-297, Inspection, Test, and Operating Status } \\
\text { HNF-PRO-334, } \begin{array}{l}\text { Criticality Safety: General Requirements } \\
\text { System Testing/Inspecting and Maintenance }\end{array} \\
\text { HNF-PRO-443, Facility Deactivation Requirements } \\
\text { HNF-PRO-488, Repair of ASME-Coded Pressure Systems } \\
\text { HNF-PRO-551, Construction Program }\end{array}$ & Note: See FDNW PEP/PPM for Other Procedures \\
\hline $\begin{array}{l}\text { SECTION 6, DESIGN } \\
\text { Design Input } \\
\text { Design Process } \\
\text { Design Verification } \\
\text { Design Changes } \\
\text { Design Documentation and Records } \\
\text { Computer Software }\end{array}$ & $\begin{array}{ll}\text { HNF-PRO-097, } & \text { Engineering Design and Evaluation } \\
\text { HNF-PRO-227, } & \text { Engineering Document Identification } \\
\text { HNF-PRO-239, Design Analysis Reports } \\
\text { HNF-PRO-240, Engineering TBDs/HOLDs } \\
\text { HNF-PRO-241, Engineering Specification Requirements } \\
\text { HNF-PRO-242, Engineering Drawing Requirements } \\
\text { HNF-PRO-243, Interface Control Requirements } \\
\text { HNF-PRO-244, Engineering Data Transmittal Requirements } \\
\text { HNF-PRO-265, } & \text { Developing and Maintaining SRIDs } \\
\text { HNF-PRO-317, } & \text { Engineering Release and Approval } \\
& \text { Requirements } \\
\end{array}$ & $\begin{array}{l}\text { 134.042.0150, } \begin{array}{l}\text { Quality Engineering-Design Review } \\
\text { 134.042.0155, Developing Quality Assurance Criteria } \\
\text { for Design Documents }\end{array} \\
\text { Note: See FDNW PEP/PPM for Other Procedures }\end{array}$ \\
\hline
\end{tabular}


HNF-SD-W460-QAPP-001

Rev. 0

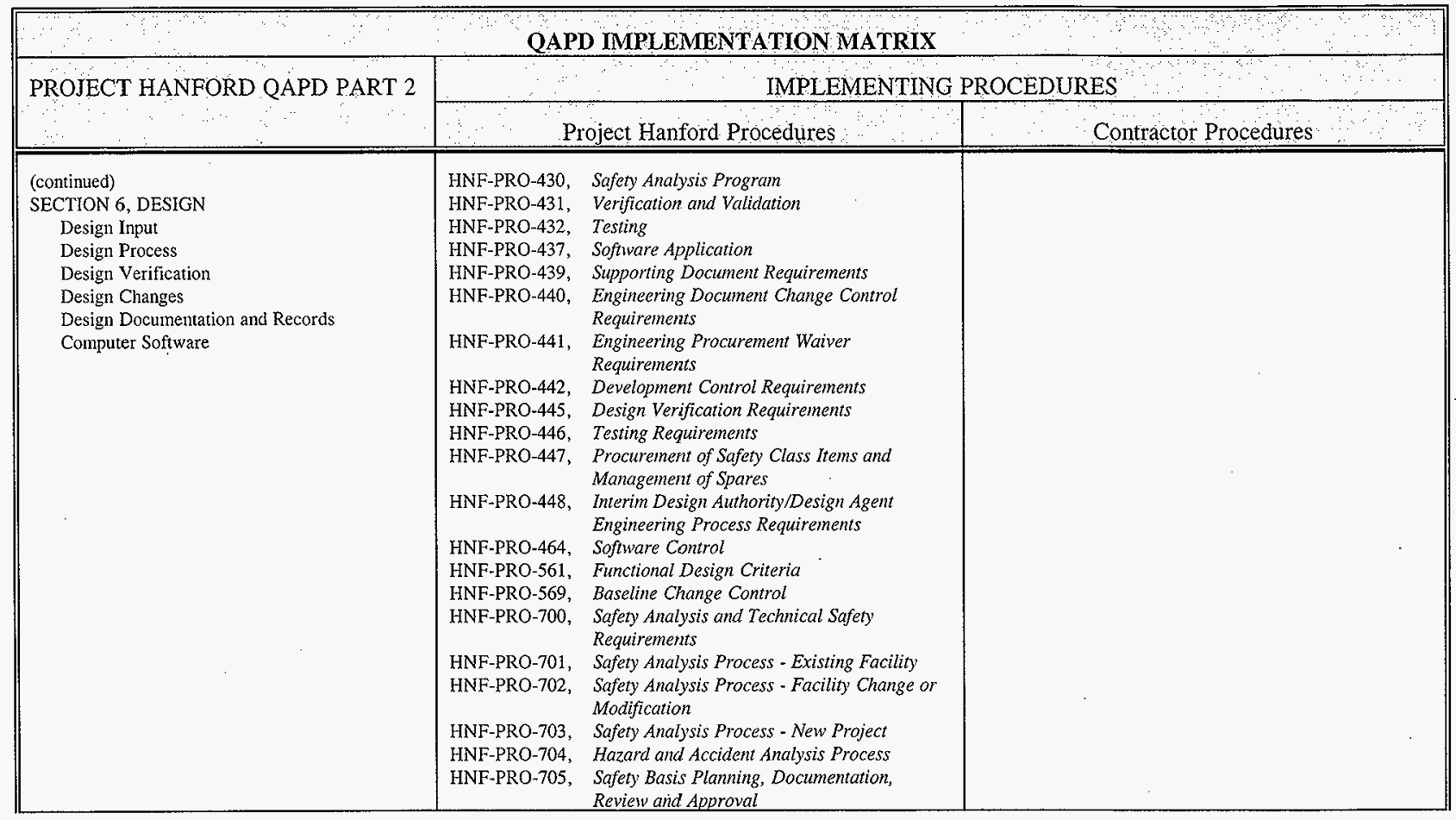




\begin{tabular}{|c|c|c|}
\hline \multicolumn{3}{|c|}{ QAPD IMPLEMENTATION MATRIX } \\
\hline \multirow{2}{*}{ PROJECT HANFORD QAPD PART 2} & \multicolumn{2}{|c|}{ IMPLEMENTING PROCEDURES } \\
\hline & Project Hanford Procedures & Contractor Procedures \\
\hline $\begin{array}{l}\text { SECTION 7, PROCUREMENT } \\
\text { Procurement Planning } \\
\text { Content of Procurement Documents } \\
\text { Supplier Evaluation and Selection } \\
\text { Control of Supplier Nonconformance } \\
\text { Acceptance of Items and Services } \\
\text { Commercial Grade Items } \\
\text { Control of Supplier-Generated Documents } \\
\text { Control of Suspect/Counterfeit Items }\end{array}$ & 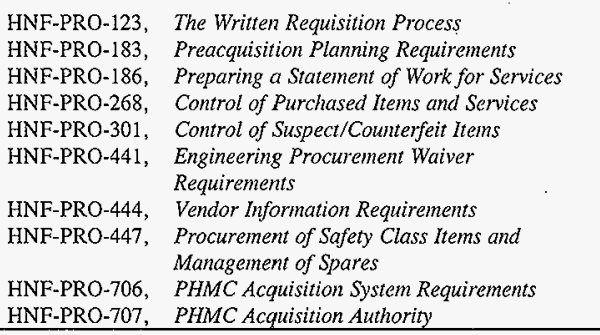 & $\begin{array}{ll}\text { 134.042.0165, } & \begin{array}{l}\text { Supplier Evaluation (Project Hanford } \\
\text { Work) }\end{array} \\
134.042 .0170, & \text { Source Surveys } \\
134.042 .0175, & \text { Procurement Document Review } \\
134.042 .0195, & \text { Procurement Support Planning } \\
& \\
\text { Note: See FDNW PEP/PPM for Other Procedures }\end{array}$ \\
\hline $\begin{array}{l}\text { SECTION 8, INSPECTION AND } \\
\text { ACCEPTANCE TESTING } \\
\text { Inspection and Acceptance Planning } \\
\text { Inspection and Acceptance Process } \\
\text { Inspection and Acceptance Testing Results } \\
\text { Inspection and Testing Status } \\
\text { Calibration of Measuring and Test Equipment }\end{array}$ & $\begin{array}{ll}\text { HNF-PRO-263, } & \begin{array}{l}\text { Qualification and Certification of Inspection } \\
\text { and Test Persomnel } \\
\text { HNF-PRO-283, }\end{array} \\
\text { HNF-PRO-286, } & \text { Test Control Inspections } \\
\text { HNF-PRO-446, } & \text { Testing Requirements } \\
\text { HNF-PRO-489, } & \text { Third Party Inspections } \\
\text { HNF-PRO-490, } & \text { Control of Measuring and Test Equipment and } \\
& \text { Non-Data Test Equipment } \\
\end{array}$ & $\begin{array}{l}\text { 134.042.0155, Developing Quality Assurance Criteria } \\
\text { for Design Documents }\end{array}$ \\
\hline $\begin{array}{l}\text { SECTION 9, MANAGEMENT ASSESSMENT } \\
\text { Management Assessments } \\
\text { Corrective Action }\end{array}$ & $\begin{array}{l}\text { HNF-PRO-052, Corrective Action Management } \\
\text { HNF-PRO-246, Management Assessment }\end{array}$ & $\begin{array}{l}\text { 134.042.0130, Management/Self-Assessments } \\
\text { Note: See FDNW PEP/PPM for Other Procedures }\end{array}$ \\
\hline
\end{tabular}




\section{B\&W Hanford Co.}

a McDermott company

\begin{tabular}{|c|c|c|c|}
\hline To & $\begin{array}{l}\text { Mr. L. J. Olguin, Project Director } \\
\text { Facility Stabilization, FDH }\end{array}$ & & \\
\hline \multirow[t]{2}{*}{ From } & & \multirow{2}{*}{$\begin{array}{l}\text { File No. } \\
\text { Or Ref.: }\end{array}$} & \multirow[b]{2}{*}{ BWHC-9853379AR3 } \\
\hline & $\begin{array}{l}\text { F. R. Crawford, Senior Director th Craw } \\
\text { Plutonium Finishing Plant Project }\end{array}$ & & \\
\hline \multirow[t]{2}{*}{ Subj } & & \multirow[t]{2}{*}{ Date: } & \multirow[b]{2}{*}{ April 22, 1998} \\
\hline & $\begin{array}{l}\text { SUBMITTAL OF HNF-SD-W460-QAPP-001, PLUTONIUM } \\
\text { STABILIZATION and HANDLING QUALITY ASSURANCE } \\
\text { PROGRAM PLAN }\end{array}$ & & \\
\hline
\end{tabular}

This letter forwards B \& W Hanford Company's "PLUTONIUM STABILIZATION and HANDLING QUALITY ASSURANCE PROGRAM PLAN”, HNE-SD-W460-QAPP-001, Rev.0.

This Quality Assurance Program Plan (QAPP) identifies project quality assurance requirements for all contractors involved in the planning and execution of Hanford Site activities for design, procurement, construction, testing and inspection for Project W-460, Plutonium Stabilization and Handling.

If you have any questions, please contact the W-460 project manager, Ms. E. V. Weiss, on 372-1109.

Attachment

evw:dg 


\section{CORRESPONDENCE DISTRIBUTION COVERSHEET}

Author

E. V. Weiss, BWHC

Subject: SUBMITTAL OF HNF-SD-W460-QAPP-001, PLUTONIUM STABILIZATION and HANDLING QUALITY ASSURANCE PROGRAM PLAN

\section{DISTRIBUTION}

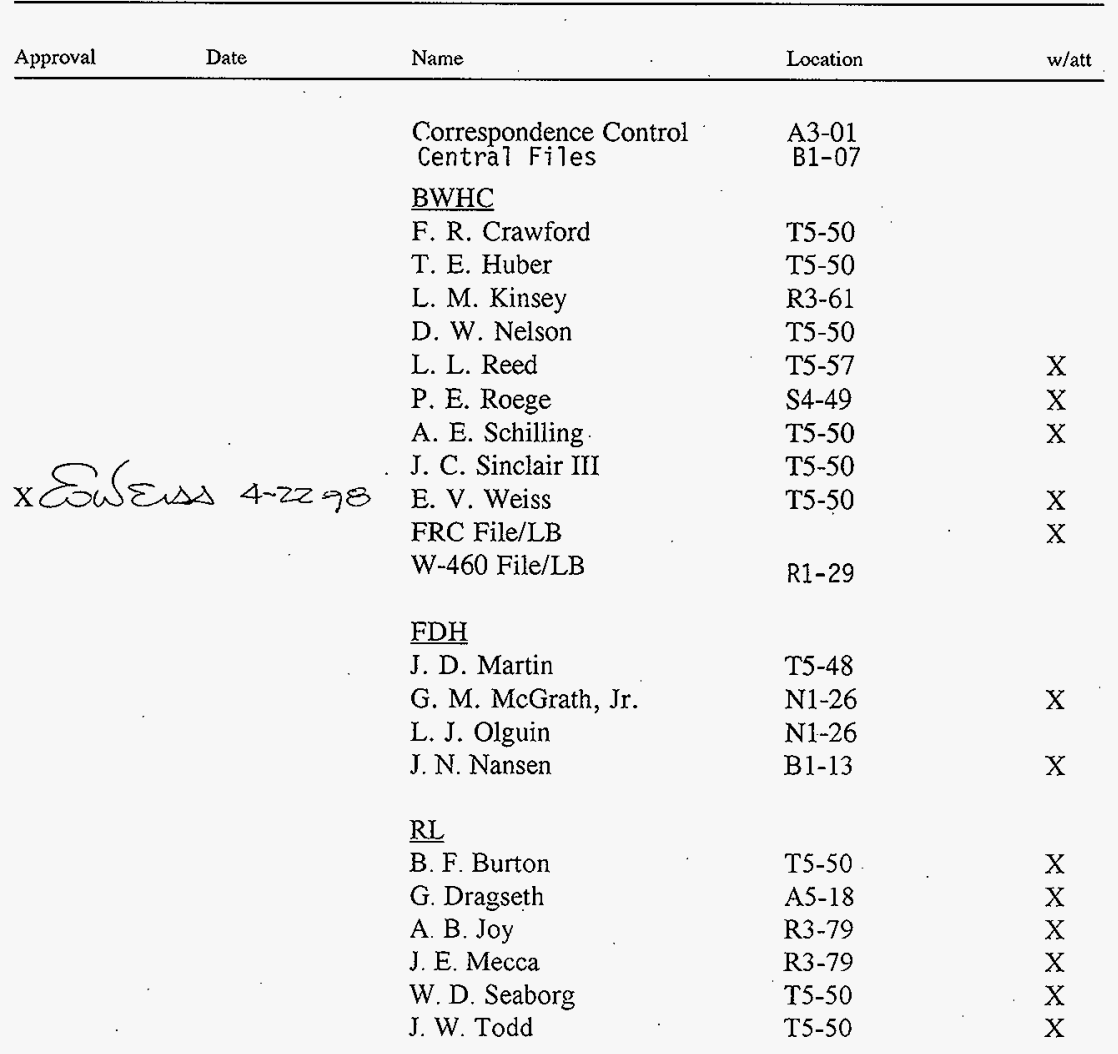

